\title{
Growth-phase-dependent expression of the lipolytic system of Acinetobacter calcoaceticus BD413: cloning of a gene encoding one of the esterases
}

\author{
Ruben G. KoK, Vincent M. Christoffels, B. Vosman† and KlaAs J. Hellingwerf* \\ Department of Microbiology, E.C. Slater Institute, BioCentrum Amsterdam, Nieuwe Achtergracht 127, \\ 1018 WS Amsterdam, The Netherlands
}

(Received 27 January 1993; revised 26 April 1993; accepted 14 May 1993)

\begin{abstract}
Acinetobacter calcoaceticus BD413, when grown in batch culture in nutrient broth, produces both extracellular lipase activity and cell-bound esterase activity during and after the transition between exponential growth and the stationary phase. From a library of $A$. calcoaceticus DNA in Escherichia coli, plasmids were isolated that enabled $E$. coli to grow on media with tributyrin as the sole carbon source. Assays with model substrates classified the product of the cloned gene as an esterase. Via deletion analysis, the esterase gene was mapped on a $1.8 \mathrm{kbp}$ chromosomal DNA fragment. This fragment was sequenced and found to contain one open reading frame, termed est $A$, which encodes a protein of $40.0 \mathrm{kDa}$. The amino acid sequence of this protein shows homology to a number of lipolytic enzymes, most notably to esterases. Deletion of est $A$ only partially abolished cell-bound esterase activity in $A$. calcoaceticus, indicating that BD413 forms at least two esterases. Both esterases show the same temporal regulation of expression. $\beta$-Galactosidase activity was measured in strains in which a promoterless lac $Z$ gene was inserted into est $A$. Induction of $l a c Z$ expression in these strains also occurred at the end of exponential growth in batch cultures, indicating that production of the esterase is regulated at the genetic level.
\end{abstract}

\section{Introduction}

Cessation of growth in bacterial batch cultures triggers the coordinate expression of many important processes. Amongst these are sporulation (Losick et al., 1989), starvation and stringent response (Cashel \& Rudd, 1987; Goldman \& Jakubowski, 1990), induction of competence for natural transformation (Dubnau, 1991), the production of secondary metabolites (Hopwood et al., 1986; Martín \& Liras, 1989) and the production of a wide variety of enzymes (Daza et al., 1991; Lange \& HenggeAronis, 1991).

\footnotetext{
* Author for correspondence. Tel. +3120 5257055; fax +3120 5257056; e-mail: a417hell@diamond.SARA.NL.
}

$\dagger$ Present address: Centre for Plant Breeding and Reproduction Research (CPRO-DLO), Postbus 16, 6700 AA Wageningen, The Netherlands.

Abbreviations: pNP, $p$-nitrophenol; pNPA, p-nitrophenyl acetate; pNPP, $p$-nitrophenyl palmitate; RBS, ribosome-binding site.

The GenBank accession number for the sequence reported in this paper is $\mathrm{X} 71598$.
The molecular mechanisms underlying the regulation of these phenomena are gradually being elucidated. Recent reports suggest that the expression of several of these growth-phase-dependent processes is controlled through central regulatory programmes (Lange \& Hengge-Aronis, 1991; Matin, 1991; Siegele \& Kolter, 1992). They may involve specific nutrient limitations, uncharged tRNAs (Goldman \& Jakubowski, 1990), positive and negative transcriptional regulators (Hoopes \& McClure, 1987), highly selective and specific promoter structures (Stragier \& Losick, 1990), alternative $\sigma$-subunits of RNA polymerase (Helmann \& Chamberlin, 1988; Stragier \& Losick, 1990) and post-transcriptional control of regulatory enzymes (Craig \& Gross, 1991).

We are interested in the physiological and genetic factors that regulate and control the expression of growth-phase-dependent genes. As a model we selected the lipolytic system of Acinetobacter calcoaceticus BD413 (Juni \& Janik, 1969). Several Acinetobacters have been shown to produce lipolytic enzymes (Breuil \& Kushner, 1975; Shabtai \& Gutnick, 1985; Haferburg \& Kleber, 1983). However, the regulation of the production of these enzymes has not been addressed at the molecular level. Esterases and lipases are carboxylic ester hydro- 
lases (EC 3.1.1) that generally have an essential serine residue at their active site (Brady et al., 1990). The carboxylesterases (EC 3.1.1.1) hydrolyse water-soluble or emulsified esters with relatively short fatty acid chains, whereas lipases (triacylglycerol acyl hydrolases; EC 3.1.1.3) preferentially attack emulsified substrates with long-chain fatty acids. A. calcoaceticus strain BD413 produces cell-bound esterase activity (Gutnick et al., 1991) and extracellular lipase activity. Additionally, the state of high competence for natural transformation makes this organism, more than other Acinetobacters, ideally suited for molecular studies (Juni, 1972; Palmen et al., 1993).

In this report, we describe the expression of the lipolytic system of $A$. calcoaceticus BD413, as well as the cloning and characterization of one of the genes involved, encoding a cell-bound esterase.

\section{Methods}

Bacteria and plasmids. These are listed in Table 1.

Media and culture conditions. Strains of Acinetobacter and E. coli were grown in LB medium [ $5 \mathrm{~g} \mathrm{NaCl}, 5 \mathrm{~g}$ Yeast Extract (Difco) and $10 \mathrm{~g}$ Bacto-Tryptone (Difco) per litre (pH 7.4)] or nutrient broth (Nbroth; Gibco). The basis for the minimal medium, with tributyrin as the sole carbon and energy source, consisted of $100 \mathrm{mM}-\mathrm{NH}_{4} \mathrm{Cl}, 10 \mathrm{mM}-$ $\mathrm{KCl}, 2 \mathrm{~mm}-\mathrm{Na}_{2} \mathrm{SO}_{4}, 1.25 \mathrm{~mm}-\mathrm{MgCl}_{2}, 20 \mu \mathrm{M}-\mathrm{CaCl}_{2}, 2 \mathrm{~mm}$-citric acid and, per litre, $5 \mathrm{ml}$ of a trace-element solution containing $5 \mathrm{mM}-\mathrm{ZnO}$, $20 \mathrm{~mm}-\mathrm{FeCl}_{3}, 10 \mathrm{~mm}-\mathrm{MnCl}_{2}, 1 \mathrm{~mm}-\mathrm{CuCl}_{2}, 2 \mathrm{~mm}-\mathrm{CoCl}_{2}, 1 \mathrm{~mm}-\mathrm{H}_{3} \mathrm{BO}_{3}$, $16 \mu \mathrm{M}-\mathrm{Na}_{2} \mathrm{MoO}_{4}$ and $100 \mathrm{mM}-\mathrm{HCl}$. After sterilization, $50 \mathrm{~mm}-\mathrm{NaP}$ buffer $(\mathrm{pH} 7.0)$ and $1 \%(\mathrm{v} / \mathrm{v})$ tributyrin were added to the basal medium. Proline and thiamin were added to a final concentration of $100 \mu \mathrm{g} \mathrm{ml}^{-1}$ and $1 \mu \mathrm{g} \mathrm{m}^{-1}$, respectively. For plates, liquid media were solidified with $1.5 \%(\mathrm{w} / \mathrm{v})$ agar.

For esterase indicator plates, $3 \mathrm{ml}$ of an emulsion of $50 \%(\mathrm{v} / \mathrm{v})$ tributyrin and $5 \%(\mathrm{w} / \mathrm{v})$ gum arabic was added to $100 \mathrm{ml}$ of molten $\mathrm{N}-$ broth agar medium. Tributyrin was emulsified, using a Branson 250 sonifier and a microtip, for $3 \mathrm{~min}$ at $75 \mathrm{~W}$ (duty cycle $100 \%$ ). Esterase production on these plates was detected by the formation of a zone of clearance around the colonies.

Two types of lipase indicator plates were used. (1) Egg-yolk plates. For these, $1.5 \%$ (v/v) egg-yolk emulsion (Oxoid) was added to molten $\mathrm{N}$-broth agar containing $1 \%(\mathrm{w} / \mathrm{v}) \mathrm{NaCl}$. Lipase production on these plates gives a turbid halo around a colony (Willis \& Gowland, 1962; Nitsch \& Kutzner, 1969). (2) Olive oil plates. For these plates, $2 \%$ (v/v) olive oil and $0.04 \mathrm{~mm}$-rhodamine $\mathrm{B}$ were added to molten $\mathrm{N}$-broth agar, containing $1 \%(\mathrm{w} / \mathrm{v}) \mathrm{NaCl}$. Production of lipase(s) on these plates is detected by the formation of a fluorescent zone around the colonies (Kouker \& Jaeger, 1987).

Antibiotics were used at the following final concentrations, in plates and in liquid media: ampicillin, $100 \mu \mathrm{g} \mathrm{m}^{-1}$; chloramphenicol, $50 \mu \mathrm{g} \mathrm{ml}^{-1}$ for A. calcoaceticus and $20 \mu \mathrm{g} \mathrm{ml}^{-1}$ for E. coli; kanamycin, $15 \mu \mathrm{g} \mathrm{ml}^{-1}$ for $A$. calcoaceticus and $50 \mu \mathrm{g} \mathrm{ml}^{-1}$ for $E$. coli; tetracycline, $15 \mu \mathrm{g} \mathrm{ml}^{-1}$.

Chemicals. Restriction enzymes and T4 DNA ligase were used as recommended by the manufacturer (Pharmacia LKB Biotechnology).

DNA isolation. Chromosomal DNA was isolated as described by Vosman \& Hellingwerf (1991). Plasmid DNA was purified by the method of Ish-Horowicz \& Burke (1981). All additional molecular genetic techniques were performed according to Sambrook et al. (1989).

Transformations. Plasmids were transformed into $E$. coli as described by Mandel \& Higa (1970). Introduction of plasmid DNA into $A$. calcoaceticus BD413 by natural transformation was performed as described by Palmen et al. (1993).

Sequence analysis. The nucleotide sequence of fragments, cloned in M13mp18 and M13mp19, was determined from both strands by the dideoxy-chain-termination method as described by Sanger et al. (1977), adapted for Sequenase version 2.0 (US Biochemical Corp.) with either the M13 universal primers or synthesized primers. The sequence data were analysed using PC/Gene (release 6.5; Intelligenetics, California) and the University of Wisconsin Genetics Computer Group (UWGCG) software (GCG package, version 7.0). The nucleotide sequence of the 1829 bp PvuII/HpaI fragment of A. calcoaceticus BD413 encoding the esterase will appear in the EMBL, GenBank and DDBJ Nucleotide Sequence Databases under accession number X71598.

Southern hybridization. Southern hybridization experiments, using non-radioactive digoxigenin-DNA-labelled probes, were performed as indicated by the supplier (Boehringer Mannheim).

$S D S-P A G E$ and immunodetection of $\beta$-galactosidase on Western blots. $\beta$-Galactosidase and the EstA- $\beta$-galactosidase fusion protein in Acinetobacter estA-lacZ fusion strain AAC313-1 (see below) were separated by SDS-PAGE ( $5 \%$, w/v, acrylamide) according to Laemmli (1970). Proteins were then blotted onto nitrocellulose according to Towbin et al. (1979) in a Bio-Rad Trans-Blot Semi-Dry Transfer Cell, for $1 \mathrm{~h}$ at $15 \mathrm{~V}$ (current limit $0.5 \mathrm{~A}$ per gel). Western blots were immunostained using polyclonal rabbit antibodies raised against $\beta$ galactosidase (kindly provided by Dr J. Tomassen) and horseradishperoxidase-conjugated goat anti-rabbit IgG (Bio-Rad), in combination with HRP-Color Development Reagent (Bio-Rad). Prior to incubation with antibodies, the transfer of proteins to the nitrocellulose membrane was verified by staining with $0.1 \%(\mathrm{w} / \mathrm{v})$ Ponceau $S$ in $5 \%(\mathrm{v} / \mathrm{v})$ acetic acid. Broad-range SDS-PAGE molecular mass standards, ranging from 6.5 to $200 \mathrm{kDa}$ (Bio-Rad) were used to calculate the difference in molecular mass between native $\beta$-galactosidase and the EstA- $\beta$ galactosidase fusion protein.

Measurement of enzyme activities and protein concentration. Esterase and lipase production was measured in $300 \mathrm{ml}$ cultures of strains grown in N-broth without antibiotics (A. calcoaceticus), or in N-broth supplemented with $50 \mathrm{mM}-\mathrm{KP}_{\mathrm{i}}(\mathrm{pH} 7.0), 1 \mathrm{mM}$-glucose and the appropriate antibiotics $(E$. coli). Under these conditions, exponential growth and an abrupt transition to the stationary phase were observed. Cultures were inoculated at an $\mathrm{OD}_{540}$ of $0 \cdot 1$, with cells from an overnight culture in the same medium. Cells were grown in MultiGen fermenter vessels (New Brunswick Scientific Co.), with saturating aeration at $30^{\circ} \mathrm{C}(A$. calcoaceticus $)$ or $37^{\circ} \mathrm{C}(E$. coli $)$. The $\mathrm{OD}_{540}$ was recorded as a representation of growth.

Culture samples $(5 \mathrm{ml})$ were centrifuged at $3000 \mathrm{~g}$ for $10 \mathrm{~min}$ at $0^{\circ} \mathrm{C}$. Part of the supernatant was retained for determination of extracellular lipase activity. Cells were washed once in ice-cold $20 \mathrm{~mm}$-HEPES buffer $(\mathrm{pH} 7 \cdot 0)$ and resuspended in the same buffer $(5 \mathrm{ml})$. A small part of the suspension was then used for the determination of protein concentration (by the method of Bradford, 1976) and (when necessary) kept on ice for subsequent determination of $\beta$-galactosidase activity. The remainder of the suspension was sonicated on ice at $75 \mathrm{~W}$ (duty cycle: $50 \%$ ) for $3 \mathrm{~min}$ using a Branson 250 sonifier with a microtip. These sonicated suspensions were immediately used for the determination of cell-bound esterase activity.

Esterase assay: $36 \mathrm{mg}$ p-nitrophenyl acetate (pNPA; Sigma) was dissolved in $1 \mathrm{ml}$ methanol. Of this stock solution, $100 \mu \mathrm{l}$ was added to $20 \mathrm{ml} 20 \mathrm{~mm}$-HEPES (pH 7.0) to yield a final pNPA concentration of 
Table 1. Strains of E. coli and A. calcoaceticus, plasmids and phages used in this study

\begin{tabular}{|c|c|c|c|}
\hline Strain/plasmid/phage & Relevant characteristics* & Marker(s) & Reference \\
\hline \multicolumn{4}{|l|}{ Strains } \\
\hline E. coli JM83 & $\Delta l a c(p r o A B)$, thi, $(\phi 80$ lac $Z \Delta \mathrm{M} 15)$ & & Yanisch-Perron et al. (1985) \\
\hline E. coli $\mathrm{DH} 5 \alpha$ & $\Delta l a c \mathrm{U} 169(\phi 80$ lac $Z \Delta \mathrm{M} 15)$ rec $A 1$ thi-1 relA1 & & Hanahan (1983) \\
\hline E. coli $\mathrm{TG} 1$ & $\begin{array}{l}\text { sup } E \text { hsd } \Delta 5 \text { thi } \Delta(\text { lac-proAB }) \mathrm{F}^{\prime}\left[\text { traD36 proA } B^{+} \text {lacI }\right. \\
\text { lac } Z \Delta \mathrm{M} 15]\end{array}$ & & Gibson (1984) \\
\hline A. calcoaceticus BD413 & Wild-type & & Juni (1972) \\
\hline A. calcoaceticus AAC $311-2 \dagger$ & $(\Delta 4.3 \mathrm{kbp}$ est $A, E \mathrm{I})::(3.5 \mathrm{kbp} \mathrm{Cm}, E \mathrm{I})$ & $\mathrm{Cm}^{\mathrm{r}}$ & This study \\
\hline A. calcoaceticus AAC $312 \dagger$ & $(\Delta 2.4 \mathrm{kbp}, \mathrm{Hp} / \mathrm{Sm})::(3.5 \mathrm{kbp} \mathrm{Cm}, E \mathrm{I})$ & $\mathrm{Cm}^{\mathrm{r}}$ & This study \\
\hline A. calcoaceticus AAC $313-1 \dagger$ & est $A::(4.3 \mathrm{kbp}$ lac $Z-\mathrm{Km}(\rightarrow), S),(\Delta 0.34 \mathrm{kbp}$ est $A, S)$ & $\mathrm{Km}^{\mathrm{r}}$ & This study \\
\hline A. calcoaceticus AAC $313-2 \dagger$ & est $A::(4.3 \mathrm{kbp}$ lac $Z-\mathrm{Km}(\leftarrow), S),(\Delta 0.34 \mathrm{kbp}$ est $A, S)$ & $\mathrm{Km}^{\mathrm{r}}$ & This study \\
\hline \multicolumn{4}{|l|}{ Plasmids and phages } \\
\hline M13mp 18 & $\alpha \operatorname{lac} Z$ & & Yanisch-Perron et al. (1985) \\
\hline M13mp19 & $\alpha l a c Z$ & & Yanisch-Perron et al. (1985) \\
\hline pAKA10 & pUN121, Bc: :estA (5.4 kbp, Sau) & $A p^{r}, T c^{r}$ & This study \\
\hline pAKA20 & pUN121, Bc::estA $(5.7 \mathrm{kbp}$, Sau) & $\mathrm{Ap}^{\mathrm{r}}, \mathrm{Tc}^{\mathrm{r}}$ & This study \\
\hline pAKA24 & pUN121, Bc: : est A $(5 \cdot 3 \mathrm{kbp}$, Sau) & $\mathrm{Ap}^{\mathrm{r}}, \mathrm{Tc}^{\mathrm{r}}$ & This study \\
\hline pAKA24-5 & pUN121, Sm/EI: :estA $(2.8 \mathrm{kbp}, P v / E \mathrm{I})$ & $\mathrm{Ap}^{\mathrm{r}}, \mathrm{T} \mathrm{c}^{\mathrm{r}}$ & This study \\
\hline pAKA10-1 $\dagger$ & $\begin{array}{l}\text { (7.4 kbp pAKA10, Hp/Sm): }(3.5 \mathrm{kbp} \mathrm{Cm}, S m, \text { of } \\
\text { pMTL24p-Cm) }(\Delta 2.4 \mathrm{kbp}, H p / S m)\end{array}$ & $\mathrm{Ap}^{\mathrm{r}}, \mathrm{Cm}^{\mathrm{r}}, \mathrm{Tc}^{\mathrm{r}}$ & This study \\
\hline pAKA1024-3† & $\begin{array}{l}(2 \cdot 2 \mathrm{kbp} \text { pAKA } 10, E \mathrm{I} / S m)::(5.6 \mathrm{kbp} \text { pAKA } 24, \\
E \mathrm{I} / E \mathrm{~V}),(\Delta 4.3 \mathrm{kbp} \text { est } A, E \mathrm{I})\end{array}$ & $\mathrm{Ap}^{\mathrm{r}}, \mathrm{Tc}^{\mathrm{s}}$ & This study \\
\hline pAKA1024-32 $\dagger$ & pAKA1024-3::(3.5 kbp Cm, $E \mathrm{I}$, of pMTL24p-Cm) & $\mathrm{Ap}^{\mathrm{r}}, \mathrm{Cm}^{\mathrm{r}}$ & This study \\
\hline pAKA20A $\dagger$ & $\begin{array}{l}\text { pAKA20 } \Delta(0.34 \mathrm{kbp} \text { est } A, S)::(4 \cdot 7 \mathrm{kbp} \operatorname{lac} Z-\mathrm{Km}(\rightarrow), \\
S)\end{array}$ & $\mathrm{Ap}^{\mathrm{r}}, \mathrm{Km}^{\mathrm{r}}, \mathrm{Tc}^{\mathrm{r}}$ & This study \\
\hline pAKA20B $\dagger$ & $\begin{array}{l}\text { pAKA20 } \Delta(0.34 \mathrm{kbp} \text { est } A, S)::(4.7 \mathrm{kbp} \text { lac } Z-\mathrm{Km}(\leftarrow) \text {, } \\
S)\end{array}$ & $A p^{r}, K^{r}{ }^{r}, T c^{r}$ & This study \\
\hline pKOK6 & pUC4K based; contains a $4.7 \mathrm{kbp}$ lac $Z-\mathrm{Km}$ cassette & $A p^{r}, \mathrm{Cm}^{\mathrm{r}}, \mathrm{Km}^{\mathrm{r}}$ & Kokotek \& Lotz (1989) \\
\hline $\mathrm{pKT} 210$ & IncQ, replicates in E. coli and A. calcoaceticus & $\mathrm{Cm}^{\mathrm{r}}, \mathrm{Sm}^{\mathrm{r}}$ & Bagdasarian et al. (1981) \\
\hline pMTL24p & alacZ & $\operatorname{Ap}^{r}$ & Chambers et al. (1988) \\
\hline pMTL24p-Cm & pMTL24p: :(3.5 kbp Cm, $P$, of pKT210) & $\mathrm{Ap}^{\mathrm{r}}, \mathrm{Cm}^{\mathrm{r}}$ & This study \\
\hline pUN121 & ColEl, Tc(cI) & $\mathrm{Ap}^{\mathrm{r}}, \mathrm{T} \mathrm{c}^{\mathrm{s}}$ & Nilsson et al. (1983) \\
\hline
\end{tabular}

* The sizes (in kbp) of relevant DNA fragments and restriction enzymes used for their isolation are indicated. Restriction enzymes indicated: $B c$, $B c l \mathrm{I} ; E \mathrm{I}, E c o \mathrm{RI}$; EV, EcoRV; Hp, HpaI; P, PstI; Pv, PvuII;Sm, SmaI ; S, SalI; Sau, Sau3A. Cm, fragment encoding chloramphenicol resistance, originally isolated from pKT210; lac Z-Km, the cassette of pKOK6 containing a promoterless lac $Z$ gene and the nptII gene encoding resistance to kanamycin. $\mathrm{Ap}^{\mathrm{r}}, \mathrm{Cm}^{\mathrm{r}}, \mathrm{Km}^{\mathrm{r}}, \mathrm{Sm}^{\mathrm{r}}$ and $\mathrm{Tc}^{\mathrm{r}}$ refer to resistance to ampicillin, chloramphenicol, kanamycin, streptomycin and tetracycline, respectively.

$\dagger$ The construction of plasmids and strains of $A$. calcoaceticus carrying different deletions and insertions is described in Methods.

$1 \mathrm{mM}$ in the assay. Sonicated cell suspension $(20-200 \mu \mathrm{l})$ was added to the substrate in a final volume of $2 \mathrm{ml}$. The reactions were carried out at $30^{\circ} \mathrm{C}$ in a Beckman DU-40 spectrophotometer. The esterase activity was calculated from the initial rate of $p$-nitrophenol (pNP) formation, measured spectrophotometrically at $410 \mathrm{~nm}$. The molar absorption coefficient of pNP at pH 7.0 was determined to be $10400 \mathrm{M}^{-1}$. One unit of enzyme activity is defined as the amount of enzyme forming $1 \mu \mathrm{mol} \mathrm{pNP} \min ^{-1}$.

Lipase assay: $37.5 \mathrm{mg}$-nitrophenyl palmitate (pNPP; Sigma) was dissolved in $2 \mathrm{ml}$ 2-propanol at $60^{\circ} \mathrm{C}$. Fifty millilitres of a buffer containing $50 \mathrm{~mm}$-Tris $/ \mathrm{HCl}(\mathrm{pH} 8.0)$ and $0.1 \%$ Triton $\mathrm{X}-100$ was prewarmed to $60^{\circ} \mathrm{C}$. The pNPP solution was suspended dropwise in this Tris buffer, while stirring vigorously, yielding a final pNPP concentration of $2 \mathrm{mM}$. Culture supernatant $(20-200 \mu \mathrm{l})$ was added to the substrate in a final volume of $2.0 \mathrm{ml}$. The reactions and activity calculations were carried out as described for the esterase assay. The molar absorption coefficient of pNP in the assay buffer ( $\mathrm{pH} 8.0$ ) was determined to be $15100 \mathrm{M}^{-1}$.

$\beta$-Galactosidase assay: the $\beta$-galactosidase activity was determined in washed cell suspensions according to Miller (1982).

Construction of mutant strains of A. calcoaceticus BD413. Complete and partial deletions of the esterase encoding region in the chromosome of Acinetobacter BD413, were generated as follows.
(1) The $0.34 \mathrm{kbp} \mathrm{SalI}$ fragment of the esterase-encoding region was deleted from pAKA20 (see Results and Discussion, Fig. 2) and replaced by the lacZ-Km cassette of pKOK6, isolated as a $4.7 \mathrm{kbp} \mathrm{SalI}$ fragment. This cassette contains a promoterless lac $Z$ gene and the $n p t I I$ gene, encoding resistance to kanamycin (Kokotek \& Lotz, 1989). The resulting plasmids, pAKA20A and pAKA20B, containing this cassette in the two orientations, were introduced into $A$. calcoaceticus BD413 via natural transformation. Prior to transformation, the plasmids were digested with $K p n I$ and $B g l I I$, both cutting in the vector part of the plasmid, to prevent replication and Campbell-like integration into the chromosome. Several kanamycin-resistant strains were isolated from transformations with both plasmids. In all strains the Sall fragment of the esterase-encoding region was replaced by the lacZ-Km cassette. One of the transformants, carrying the deletion of pAKA20A, yielded strain AAC313-1; pAKA20B gave strain AAC313-2.

(2) A deletion of the complete esterase encoding region in $A$. calcoaceticus was constructed as follows. A $5.6 \mathrm{kbp}$ EcoRI/EcoRV fragment of pAKA24 (left-hand fragment in Fig. 2), was ligated to a $2.2 \mathrm{kbp} E c o$ RI/SmaI fragment of pAKA10 (right-hand fragment in Fig. 2). The latter fragment was isolated from a complete $E c o R I /$ partial $S m a$ I digestion of pAKA10. This indirectly deleted the $4.3 \mathrm{kbp} E c o$ RI fragment present in pAKA20, containing the entire esterase-encoding region and simultaneously deleted the $890 \mathrm{bp} \mathrm{SmaI/EcoRV} \mathrm{fragment}$ of the vector, carrying part of the tetracycline-resistance gene. The 
resulting plasmid (pAKA1024-3) contained the chromosomal fragment of pAKA10 flanking the right-hand EcoRI site on the insert in pAKA20, and the region of pAKA24 flanking the left-hand EcoRI site on the insert of pAKA20 (see Fig. 2). The chloramphenicol-resistance gene of pKT210, isolated as a PstI fragment and cloned in the PstI site of pMTL24p (yielding pMTL24p-Cm), was subsequently isolated as a $3.5 \mathrm{kbp} E c o \mathrm{RI}$ fragment. This fragment was inserted into the unique EcoRI site of pAKA1024-3, between the two EcoRI-flanking sequences. This yielded plasmid pAKA1024-32, in which the fragment encoding resistance to chloramphenicol $\left(\mathrm{Cm}^{\mathrm{r}}\right)$ replaced the entire $4.3 \mathrm{kbp} E c o \mathrm{RI}$ region encoding the esterase. pAKA1024-32 was then introduced into A. calcoaceticus BD413. ColE1 replicons do replicate, although poorly, in Acinetobacter (Vosman et al., 1991). Therefore, kanamycin-resistant colonies were replica-plated onto plates containing ampicillin (resistance to ampicillin was encoded by the vector part of pAKA102432). Strains sensitive to this antibiotic were isolated as true deletion mutants, having replaced their esterase-encoding region by the $\mathrm{Cm}^{\mathrm{r}}$ gene via replacement recombination. One of the resulting deletion mutants was named AAC311-2.

(3) A third type of deletion mutant of BD413, lacking the $2.4 \mathrm{kbp}$ HpaI/SmaI fragment of pAKA10, downstream of the esteraseencoding region, was generated as follows. A plasmid (pAKA10-1) was constructed in which this fragment was replaced by the chloramphenicol-resistance gene of pKT210, isolated as a partial SmaI fragment of pMTL24p-Cm. To prevent replication of the plasmid, and/or its insertion into the chromosome via a Campbell-like integration, pAKA10-1 was linearized with $N r u$ I (which cuts in the vector part) before introduction into $A$. calcoaceticus BD413 via natural transformation. One chloramphenicol-resistant strain, carrying the deletion of pAKA10-1, was named AAC312.

Verification of chromosomal mutations via Southern hybridization. (1) AAC313-1 and AAC313-2. The 0-34 Sall est $A$ fragment hybridizes to Sal I-digested chromosomal DNA of wild-type BD413. However, no hybridizing signal could be found with the lacZ-Km insertion mutants AAC313-1 and AAC313-2, showing that the $S a l I$ fragment was indeed deleted from these two mutants. The lacZ-Km cassette of pKOK6 carries two EcoRI restriction sites, one at the start of the $l a c Z$ gene, the other just at the end of the lac $Z$ gene (see also Fig. 2). In AAC313-1 one of these EcoRI sites is situated just downstream of the SalI site in est A; in AAC313-2 an EcoRI site is introduced $1.6 \mathrm{kbp}$ downstream of the est $A$ SalI site. As expected, when the $2.0 \mathrm{kbp} \mathrm{EcoRI/SalI} \mathrm{estA}$ fragment of pAKA24 was used as a probe, a $2.0 \mathrm{kbp}$ hybridizing fragment was found in EcoRI-digested DNA of AAC313-1 and an EcoRI fragment of $3.6 \mathrm{kbp}$ was found to hybridize in AAC313-2 DNA. In EcoRI-digested DNA of BD413, hybidization was found with the $4.3 \mathrm{kbp}$ wild-type fragment.

(2) $A A C 311-2$ and $A A C 312$. Using the $1.47 \mathrm{kbp} P v u \mathrm{II} / S p h \mathrm{I}$ fragment of the esterase region (see Results and Discussion, Fig. 4) as a probe, again the $4.3 \mathrm{kbp}$ hybridizing fragment was found in chromosomal DNA of wild-type BD413 digested with EcoRI. However, this hybridizing band was absent in EcoRI-digested DNA of AAC311-2. When the $3.5 \mathrm{kbp} E c o$ RI $\mathrm{Cm}^{\mathrm{r}}$ fragment was used as a probe, an $E c o$ RI fragment of the same size was found to hybridize in EcoRI digested chromosomal DNA of AAC311-2, whereas no hybridization was obtained with BD413 DNA. With both the estA probe and the $\mathrm{Cm}^{\mathrm{r}}$ probe, a hybridizing fragment of approximately $8.5 \mathrm{kbp}$ was found in EcoRI-digested DNA of mutant AAC312, confirming that the estA gene was still present in this mutant and that the $\mathrm{Hpal} / \mathrm{SmaI}$ fragment had been replaced by the $\mathrm{Cm}^{\mathrm{r}}$ fragment. As expected, neither AAC3112 nor AAC312 (testing EcoRI-digested DNA from both strains) showed a hybridizing signal when the $1.6 \mathrm{kbp} \mathrm{HpaI} / E c o \mathrm{RI}$ fragment of pAKA10 (the fragment downstream of est $A$ ) was used as a probe, confirming deletion of the $4.3 \mathrm{kbp}$ EcoRI fragment in AAC311-2 and deletion of the $2 \cdot 4 \mathrm{kbp} \mathrm{HpaI} / \mathrm{SmaI}$ fragment in AAC312.

\section{Results and Discussion}

\section{The lipolytic system of A. calcoaceticus BD413}

A. calcoaceticus BD413, like the psychrophilic Acinetobacter 016 (Breuil \& Kushner, 1975), produces both esterase activity and lipase activity during growth on complex media such as N-broth (Fig. 1). The esterase activity, measured via hydrolysis of $p$-nitrophenyl acetate (pNPA), was cell-bound and remained so during prolonged incubation (not shown). In contrast, Breuil \& Kushner (1975) reported that the Acinetobacter 016 esterase is cell-bound only during early growth and is detected in the extracellular medium late in growth. A similar situation was described for A. calcoaceticus RAG-1 (Shabtai \& Gutnick, 1985). As has been described for Acinetobacter lwoffi O16 (Breuil \& Kushner, 1975 ) and A. calcoaceticus $69 \mathrm{~V}$ (Haferburg \& Kleber, 1983), lipolytic activity in cultures of BD413, measured with $p$-nitrophenyl palmitate (pNPP), was secreted into the culture supernatant. This activity could also be detected titrimetrically, using olive oil as a substrate.

In cultures of $A$. calcoaceticus BD413 grown in Nbroth, $99 \%$ of the pNPA-hydrolysing activity was cellbound, whereas roughly $96 \%$ of the pNPP-hydrolysing activity could be detected in the culture medium. We therefore conclude that the cell-bound activity is esterase activity and that a lipase is secreted into the medium. This lipase has been purified to homogeneity and characterized biochemically (R. G. Kok and others, unpublished experiments).

During growth in batch cultures in N-broth, $A$. calcoaceticus BD413 produced high amounts of esterase activity specifically during the transition between exponential growth and the stationary phase (Fig. 1). Within

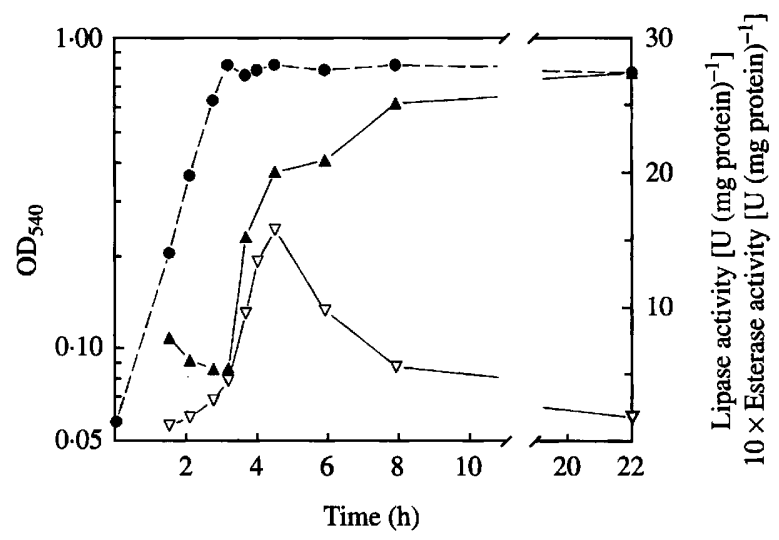

Fig. 1. Production of cell-bound esterase and extracellular lipase by $A$. calcoaceticus BD413. Cultures were grown in N-broth in fermenter vessels (see Methods). Growth $\left(\mathrm{OD}_{540}\right) ; \nabla$, specific extracellular lipase activity, measured in the culture medium with pNPP as the substrate; $\boldsymbol{\Delta}$, specific cell-bound esterase activity (NB values were $1 / 10$ those plotted), measured in sonicated cell suspensions, with pNPA as the substrate. 


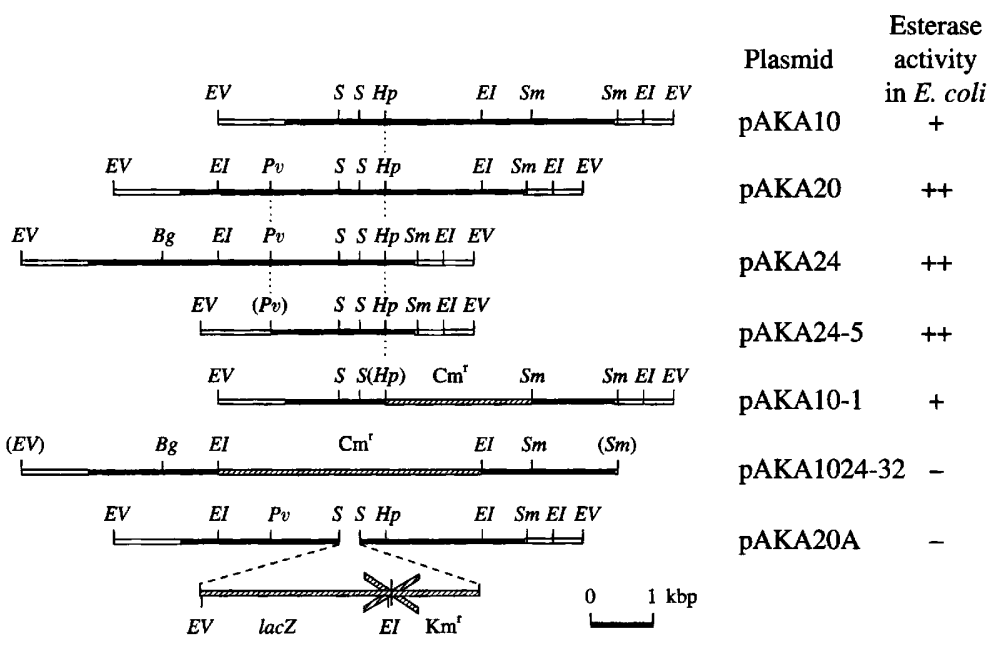

Fig. 2. Schematic representation of the $A$. calcoaceticus chromosomal inserts in different plasmids and the production of esterase by strains of E. coli JM83 carrying these plasmids. After a few days of incubation on plates with tributyrin, esterase activity was scored by the relative size of a zone of clearance around a colony. pAKA10, pAKA20 and pAKA24 were independently isolated from the gene library in $E$. coli JM83; pAKA24-5, pAKA10-1, pAKA1024-32 and pAKA20A are derivatives of these plasmids. The insert DNA is shown as a solid thick line. Vector DNA is indicated as open boxes. $\mathrm{Cm}^{\mathrm{r}}$ (hatched box) is the $3.5 \mathrm{kbp}$ chloramphenicol-resistance gene of pMTL24p::Cm (Table 1), inserted as an EcoRI fragment in pAKA1024-32 and as a SmaI fragment in pAKA10-1. lac $Z$ and $\mathrm{Km}^{\mathrm{r}}$ (hatched arrows) refer to the cassette of pKOK6 (Table 1), inserted in two orientations between the Sall sites in the esterase-encoding region in pAKA20A and pAKA20B (only pAKA20A is shown). The chromosomal inserts in the plasmids are aligned. The common fragment in the different inserts, necessary for maximal esterase expression in $E$. coli JM83 is marked with dotted lines. Only the chromosomal inserts are drawn to scale. Restriction sites; $B g, B g l \mathrm{II} ; E I, E c o \mathrm{RI} ; E V, E c o \mathrm{RV}$; $H p, H p a \mathrm{I} ; P v, P v u \mathrm{II} ; S, S a l \mathrm{I} ; S m$, SmaI. Restriction sites that have been lost during constructions are shown in parentheses.
90 min after growth had ceased, the specific esterase activity increased about fourfold, followed by a slower increase in activity during the next $3.5 \mathrm{~h}$. From this point onwards, up to at least $19 \mathrm{~h}$ after exponential growth was completed, the specific esterase activity in sonicated cell suspensions remained constant (Fig. 1). This is in sharp contrast to the situation described for A. calcoaceticus RAG-1, which produces both cell-bound and extracellular esterase activity early during exponential growth in an ethanol/minimal salts medium. Cell-bound esterase activity in this strain decreases during further growth, and an increasing amount of esterase is detected extracellularly (Shabtai \& Gutnick, 1985). Breuil \& Kushner (1975) described a situation for Acinetobacter O16 similar to $A$. calcoaceticus RAG-1 with respect to the growth-phase dependence of esterase production. Grown on complex media, Acinetobacter $\mathrm{O} 16$ produces cell-bound esterase activity specifically during the exponential phase. Decreasing esterase activities are detected when the culture reaches the stationary phase.

During the transition period, late in the growth of $A$. calcoaceticus BD413 in N-broth, lipase activity appeared in the extracellular medium (Fig. 1). Extracellular lipase activity increased about fivefold within $60 \mathrm{~min}$ of the cessation of growth. Fisher et al. (1987) reported that the secretion of extracellular lipase of $A$. calcoaceticus $69 \mathrm{~V}$ is growth-phase dependent. Only the extracellular form of the enzyme would appear at the end of exponential growth. Similar to the production of esterase, Acinetobacter $\mathrm{O} 16$ produces lipase specifically during exponential growth (Breuil \& Kushner, 1975). Unlike esterase activity, the lipase activity in cultures of $A$. calcoaceticus BD413 decreased rather sharply 90 min after the stationary phase had been reached, to about the same level as was observed during exponential growth (Fig. 1). Similar lipase activity levels were detected in the extracellular medium of overnight cultures (not shown). The decrease in activity was caused by degradation of the enzyme (as could be shown with specific antibodies; data not shown).

The combination of cell-bound esterase and extracellular lipase activity, both produced at the moment of transition of a culture to the stationary phase, has not been documented thus far. Therefore, we have selected the lipolytic system of $A$. calcoaceticus BD413 as a model for our studies on the regulation of late-growth gene expression at the molecular level.

Cloning of an esterase gene of $A$. calcoaceticus BD413 via E. coli

When grown on N-broth plates, containing $1.5 \%$ tributyrin as an indicator of lipolytic activity (Mourey \& Kilbertus, 1976), A. calcoaceticus BD413 formed a zone 


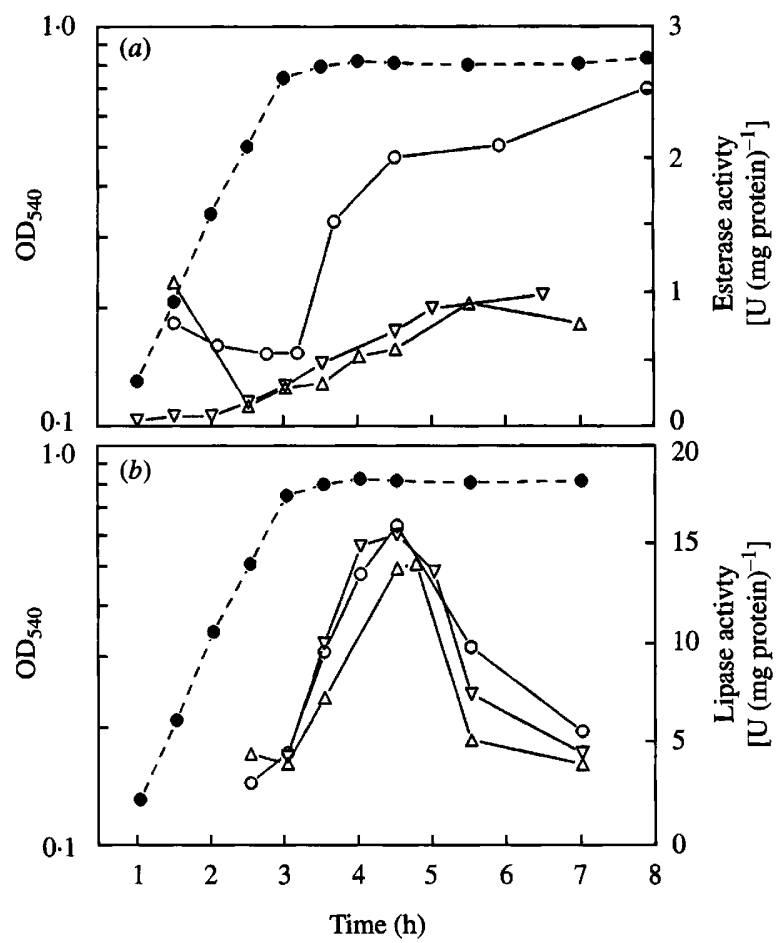

Fig. 3. Production of esterase ( $a$ ) and lipase $(b)$ in wild-type and mutant strains of $A$. calcoaceticus BD413. Growth $\left(\mathrm{OD}_{540} ; \mathbf{O}\right)$ and specific activity of cell-bound esterase and extracellular lipase was measured in batch cultures of $A$. calcoaceticus BD413 (O), AAC311-2 $(\triangle)$ and AAC313-1 $(\nabla)$, in N-Broth, in well-aerated fermenter vessels. One typical growth curve is shown. The production of esterase by AAC3132 was similar to the levels produced by AAC313-1 (not shown).

of clearance around its colonies after a few days. E. coli JM83 did not form significant haloes on tributyrin plates within two weeks. This lack of hydrolytic activity in $E$. coli was exploited to isolate a complementing gene from Acinetobacter (further analysis of this gene led to us classifying this gene as an esterase gene; see below).

A partial Sau3A gene library of $A$. calcoaceticus BD413 chromosomal DNA was constructed in $E$. coli strain JM83. Chromosomal fragments, ranging in size from 5 to $10 \mathrm{kbp}$, were ligated into $B c l \mathrm{I}$-linearized pUN121 (Nilsson et al., 1983). The ligation mixture was introduced into $E$. coli JM83 and transformants were selected on LB plates containing tetracycline and ampicillin. A total of 12000 colonies were replica-plated onto $\mathrm{N}$-broth plates containing $1.5 \%$ tributyrin as an emulsion. After $4 \mathrm{~d}$ incubation, 12 colonies had formed a zone of clearance, indicating the production of lipolytic activity. One of these strains, JM83(pAKA10), formed zones that were significantly smaller than the haloes produced by most of the other strains. One additional strain, JM83(pAKA22), only showed a zone of clearance on tributyrin plates after $8 \mathrm{~d}$ incubation.

Restriction analysis showed that the first 12 strains all contained a similar $350 \mathrm{bp} \mathrm{SalI}$ fragment, indicating that they were complemented by the same gene from Acinetobacter. The insert in pAKA22 differed entirely from the other 12. All 13 strains were able to grow in minimal medium with $1 \%$ tributyrin as the sole carbon and energy source, although JM83(pAKA22) had a lower growth rate than the other 12 (not shown). JM83(pUN121) could not grow with tributyrin as a carbon and energy source. A similar procedure (with triacetin instead of tributyrin) was used by Reddy $e t$ al. (1989) to identify clones of $E$. coli that carried the esterase gene from A. calcoaceticus RAG-1.

Mourey \& Kilbertus (1976) described tributyrin to be a lipase-specific substrate. However, McKay et al. (1992) have cloned an esterase gene from a psychrotrophic pseudomonad, which hydrolyses tributyrin. Since $A$. calcoaceticus BD413 produces both extracellular lipase activity and cell-bound esterase activity, the first 12 positive $E$. coli strains were replica-plated onto lipase indicator plates, to further characterize the activity cloned. No turbid haloes were formed on plates containing egg-yolk, nor did fluorescent zones appear on plates supplied with olive oil plus rhodamine B. However, as in $A$. calcoaceticus BD413, esterase activity could be detected in sonicated cell suspensions of cultures of the complemented strains, using p-NPA as a substrate. JM83(pUN121) did not show significant esterase activity (not shown). No activity was detected using the lipase substrate p-NPP (not shown). From these observations we concluded that the fragment cloned in the $12 \mathrm{E}$. coli strains encoded an esterase.

Mapping the esterase gene: deletion plasmids in E. coli

To obtain information about the molecular structure of the DNA fragment encoding the esterase activity in $E$. coli, a detailed restriction map was constructed of the plasmid inserts in pAKA10, pAKA20 and pAKA24 (Fig. 2). A $2.0 \mathrm{kbp}$ fragment was present in all three plasmids, suggesting that the information necessary for esterase production was contained within this region. The restriction map of this region differed entirely from the region of the esterase gene of $A$. calcoaceticus RAG1 , cloned by Reddy et al. (1989). JM83 carrying pAKA10 showed a reduction in esterase production as compared to the other two strains (Fig. 2). This could indicate that either (a part of) the regulatory region in front of the esterase gene, or sequences at the end of the gene, were not present on pAKA10. The $2.8 \mathrm{kbp} \mathrm{PvuII/EcoRI}$ fragment of pAKA24 (carrying a part of the vector), was subcloned in pUN121, digested with SmaI and EcoRI. This yielded plasmid pAKA24-5, which provided $E$. coli JM83 with the ability to degrade tributyrin, similar to pAKA20 and pAKA24 (Fig. 2), indicating that the additional 414 bp PvuII/Sau3A fragment present in this 
plasmid (in comparison with pAKA10) is important for maximal production of esterase activity.

A more detailed positioning of the esterase gene was obtained by constructing two deletion plasmids, which were subsequently used to generate the corresponding deletions in the chromosome of $A$. calcoaceticus BD413 (see below; for a more detailed description of the construction of mutants, see Methods). In the first deletion plasmid (pAKA10-1), a 2.4 kbp HpaI/SmaI fragment of pAKA10 was replaced by the $\mathrm{Cm}^{\mathrm{r}}$ fragment of pMTL24p-Cm (Fig. 2). pAKA10-1 only contained a $1.4 \mathrm{kbp}$ fragment of the esterase-encoding region. JM83(pAKA10-1) did not show a reduction in esterase activity as compared to JM83(pAKA10) (Fig. 2). Since the esterase activity in JM83 carrying either pAKA10 or pAKA10-1 was somewhat reduced as compared to JM83 carrying pAKA20, pAKA24 or pAKA24-5, the information necessary for maximal esterase expression must be located on the $1.8 \mathrm{kbp}$ fragment between the $P v u I I$ site bordering the insert in pAKA24-5 and the $H p a \mathrm{I}$ site (Fig. 2, indicated by dotted lines).

This was confirmed by constructing a second type of deletion plasmid (pAKA20A and pAKA20B) in which the $0.34 \mathrm{kbp}$ fragment between the two SalI sites in the $1.8 \mathrm{kbp}$ region was replaced by the lacZ-Km cassette from pKOK6 in two orientations. $E$. coli JM83(pAKA20A) (Fig. 2) and JM83(pAKA20B) (not shown) did not produce esterase activity.

\section{Esterase mutants of A. calcoaceticus BD413}

To test whether the esterase activity in Acinetobacter could be abolished by deleting the wild-type gene, the deletions of pAKA20A and pAKA20B, described above, were transferred to the chromosome of $A$. calcoaceticus BD413. In addition, a second esterase deletion mutant was constructed, that lacks the entire $1.8 \mathrm{kbp}$ esteraseencoding region. This mutant was constructed via a plasmid (pAKA1024-32), in which the $4.3 \mathrm{kbp} \mathrm{EcoRI}$ fragment present in pAKA20 was replaced by the chloramphenicol-resistance gene of pMTL24p-Cm (see Methods and Fig. 2).
Table 2. Maximum cell-bound esterase activities as measured in cultures of $A$. calcoaceticus strains in $N$-broth

Wild-type and mutant strains of $A$. calcoaceticus BD413 (see Table 1 and Methods for the construction of the mutant strains) were grown in batch culture in $\mathrm{N}$-broth. Esterase activity was determined at different times during growth, in sonicated cell suspensions, using pNPA as the substrate. Maximum esterase activities were used to calculate the mean maximum esterase activity, \pm SEM. $n$, Number of independent determinations.

\begin{tabular}{lc}
\hline \hline Strain of A. calcoaceticus & $\left.\begin{array}{c}\text { Maximum esterase activity } \\
{[\mathrm{U}(\mathrm{mg} \text { protein) }}\end{array}{ }^{-1}\right]$ \\
\hline BD413 (wild-type) & $2 \cdot 3 \pm 0 \cdot 3(n=12)$ \\
AAC311-2 & $0 \cdot 8 \pm 0 \cdot 2(n=2)$ \\
AAC312 & $2 \cdot 6 \pm 0 \cdot 4(n=24)$ \\
AAC313-1/2 & $1 \cdot 0 \pm 0 \cdot 1(n=5)$ \\
\hline \hline
\end{tabular}

A. calcoaceticus AAC311-2, a deletion mutant carrying the insertion of pAKA1024-32, showed reduced esterase activity on tributyrin plates (not shown) and approximately half of the wild-type activity in in vitro measurements in sonicated cell suspensions (Fig. $3 a$; Table 2). Strains AAC313-1 and AAC313-2, deletion mutants of BD413 carrying the lac Z-Km insertions of pAKA20A and pAKA20B, respectively, showed similar reduced esterase activity in sonicated cell suspensions (Fig. 3a) and on plates (not shown). However, cell-bound esterase could still be detected in these three strains, which implies that at least one additional cell-bound esterase is produced by $A$. calcoaceticus BD413. The remaining esterase activity, like the total esterase production in BD413, was produced at the onset of the stationary phase in these mutant strains (Fig. 3a). Although the increase in production of the remaining esterase activity showed a more gradual pattern than observed for the total esterase production of BD413, this implies that both esterases in BD413 are coordinately regulated and expressed in N-broth.

At present, it is not clear whether A. calcoaceticus BD413 carries two (or several) copies of the same esterase gene, or entirely different esterase genes. With

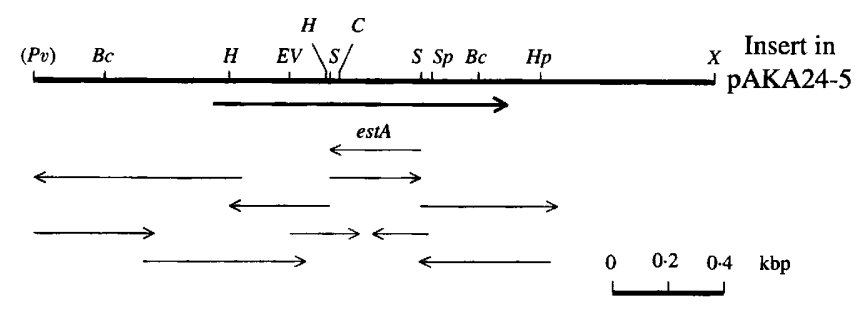

Fig. 4. Detailed restriction map of the esteraseencoding region in pAKA24-5 and the strategy for sequencing fragments of this region, cloned into M13mp18 and M13mp19. The nucleotide sequence was determined using either the M13 universal primers or synthesized primers as described in Methods. The esterase ORF (est A) is indicated with a bold arrow. Restriction sites: $B c$, $B c l \mathrm{I} ; C, C l a \mathrm{I} ; E V, E c o \mathrm{RV} ; H$, HindIII; Hp, HpaI; $S, S a l \mathrm{I} ; S p$, SphI. (Pv), PvuII site lost with construction of pAKA24-5; X, ligation $H p a \mathrm{I} /$ SmaI. 
PVUII

CAGCTGAAGCAGGTGCTTCAACTCAAACTCAACCTGTACAGGCAGCTCCTGAAGCACCACAGACAAGCCCTGATA

CTGCAACTGTTCAATAAGCAATAGTGACGCCTGCATCTTGAATAGTGCAGCCAAGGTAAAGTATCAAGGATGCCA

CCTTCACTTTACGGATTGACTCGAGCTGCTACTCAAGCAATCGCCTATTCAAGATGACATGAGCCTAAGAAATCT $B C 1 I$

CTTACAGTCTGTGTCGAGAATGACCCTAGCTCTAGCTTAAATGATCAGAGTATGATGATTGCATACAGAACAGGA

TGTACTGGAATGGTTGATTGACTTTTAAACGACATGATGTTGTTTTGCAAACCAGAGGATAAACCCCTAAATCA PAKA10

CCTTATGATTTAGGGTTTATTTATTGGAAACACTTGGATCATCCAATGTCACAAATTATTCGCAAAATAATAT

GATAATGGTATATGGCAAAATGCGACTTCCAATCCATGTTTTTTAGTCAATGACTTTTAGGGATGATCCGATTAG

CGTAAATAAACACAATAATGTGACATCTTGATTGCGTACTTTAGACAACAATAGATTCAAGAACAGATAAATTGT $\star \star \star *$

- - - - esta - - $\rightarrow$

ATCGAGAAATCAAATGACAACGACGATGAAAGGAGAGAAGAATTGACTGCATTTGTTCAAACCATTCAGGAAGTT METThrAlaPheValGlnThrIleglngluVal HindIII

TTAGAAAAAGGTCATGGGCCTGCTGCACGTGCTTTGGATAAGCTTCCTTCCTTCGTACAAGAGTCTATTGCGAAA LeuGluLysGlyHisGlyProAlaAlaArgAlaLeuAspLysLeuProSerPheValglngluSerIleAlaLys

GTTTTAGGTTATCCCTATCAGTACCCGCAGTTAGATAGCTTTATCAAATGCTTGATGGCAGTTCAAATCAAGCAA ValLeuGlyTyrProTyrGlnTyrProGlnLeuAspserPheIleLysCysLeuMetAlaValGInI leLysGln

GGTCAAACTGGGTTTATCGGCTCAGATGTCGAAAAATCACGTTTAGCCTTTGAAACTCAGATGGAGTCCATTCTT GlyGlnThrGlyPheIleGlySerAspValGluLysSerArgLeuAlaPheGluThrGlnMetGluSerIleLeu ECORV

CGCAAGCCCACAGCCATCACGTTTGTCGAAGATATCCGCTTACCATTACAAAGCGGAACTATCTTTGCACGTCAT ArgLysProThrAlaI leThrPheValgluAspI leArgLeuProLeuGInSerGlyThrIlePheAlaArgHis

TATCATCCTGCTCCAAACAAAAAATTACCTATGATTGTGTTCTATCATGGTGGAGGATTTGTGGTGGGCAATGTT 1050 TyrHisProAlaProAsnLysLysLeuProMetIleValPheTyrHisGlyGlyGlyPheValValglyAsnVal 136 HindIII $\mathrm{SaII}$ ClaI

GATACACATGATGAAGCTTGTCGACTCATTGCAAAATACGCCAATGCTCAAGTATTAAGTATCGATTATCCATTG 1125 AspThrHisAspGluAlaCysArgLeuIleAlaLysTyrAlaAsnAlaGlnValLeuSerIleAspTyrProLeu 161

GCACCAGAAGTTTCACCGCAACGACTAATTCAGTCTTGTGAAGATGCCTIAGCTTGGGTTTATCAAAACAAACGT 1200 AlaProGluValserProGlnArgLeuIleGlnSerCysGluAspAlaLeuAlaTrpValTyrglnAsnLysArg 186

CATTTTAAAATACTAAAAAATCAGATTGCCGTGGCAGGTGATAGTGCGGGTGGAAATATCAGCACCGTTGTGGCT 1275 HisPheLysIleLeuLysAsnglnIleAlaValAlaglyAspSerAlaGlyGlyAsnIleSerThrValValAla 211

CAGCGTGCGATTGGAAAAGTTTACGCACAAGATGCACAATTCCTGATTTATCCAGTAGTTGATTTTAAAAGCCGT 1350 GInArgAlaIleGlyLysValTyrAlaglnAspAlaGlnPheLeuIleTyrProValValAspPheLysSerArg 236 SaII

CATCCCTCATTTTATGCATATAAAGATGGATTGGTGCTGACTGGAAATGACGTCGACTATGTGACTGATTACTAT 1425 HisProSerPheTyrAlaTyrLysAspGlyLeuValLeuThrGlyAsnAspValAspTyrValThrAspTyrTyr 261 SphI

GCAACAAAGCATGCTGTACATTTAGATGATCCAATTATTTCGCCTACCTATGGTAATTTCAAAAAACTGGCGCCT 1500 AlaThrLysHisAlaValHisLeuAspAspProIleIleserProThrTyrGlyAsnPheLysLysLeuAlaPro 286

GCATATATTGTGACGGCTGGACATGATGTATTACATGATGAAGGCGAAATCTATAGCCATAAGCTACGTCAAGCA 1575 AlaTyrIleValThrAlaglyHisAspValLeuHisAspGluglyGluIleTyrSerHisLysLeuArgGlnAla 311 BCII

GGGGTTAAAATTCATTTTGAAGAGTACCTTGATCAAACCCATGGATTTATCAATTTGACGCCAGTTTCACATAAG 1650 GlyVallysIleHisPheGluGluTyrLeuAspGlnThrHisGlyPheIleAsnLeuThrProValserHisLys 336

GCGAGAGCAAATCTGATTCAGATGAGTAAATCATTCCGTAAATTTTGGAATAAATACGCCTGATATTAAGATCAG 1725 AlaArgAlaAsnLeuIleGlnMetSerLysSerPheArgLysPheTrpAsnLysTyrAla*** *** 356

TTGAA ATTGATACTATTTGAAGAAATAGATCAAATACACAATTAAAACAAGAGAGTAGACAGTTTATGCTATG 1800 HPaI

TTAAGTCACTTATGATAAAAGAAGTTAAC 1829 
respect to this, it is relevant to note the identification of E. coli JM83 strain carrying pAKA22 (see above). The suggestion that the insert in pAKA22 encodes a second esterase from $\boldsymbol{A}$. calcoaceticus is currently under investigation.

To our knowledge, the presence of two esterases has not been reported for other strains of Acinetobacter. It seems different from the situation described for $A$. calcoaceticus RAG-1 by Shabtai \& Gutnick (1985): Mutants of RAG-1, defective in an esterase, were unable to grow on triacetin, whereas they could still grow on acetate. Transfer of the deletion of pAKA10-1 (which had no influence on the esterase production in JM83) to Acinetobacter yielded strain AAC312. As expected, this deletion mutant exhibited the full cell-bound esterase activity as found in BD413 (Table 2), showing that also in Acinetobacter the $2.4 \mathrm{kbp} \mathrm{HpaI} / S m a \mathrm{I}$ region is not essential for the production of the esterase.

The production of extracellular lipase activity in the $A$. calcoaceticus strains mentioned above was not affected by the mutations in the esterase region (Fig. $3 b$ ). This shows that the two activities are not genetically related.

\section{Sequence analysis of the esterase encoding region}

The nucleotide sequence of the $1.8 \mathrm{kbp} \mathrm{PvuII/HpaI}$ fragment of pAKA24-5 was determined. The strategy for sequencing of this fragment is shown in Fig. 4, the nucleotide sequence and derived amino acid sequence in Fig. 5. The $1829 \mathrm{bp}$ fragment contains one open reading frame (ORF), from nucleotide 580 to 1710 . The ORF is followed by a UGA and a UAA stopcodon, separated by only three bases. The ORF was termed est $A$, because of the esterase activity it encodes (see above).

The first ATG codon in the ORF is located at nucleotide position 805 . If translation is initiated from this methionine codon, a stretch of 225 nucleotides of potentially coding DNA remains untranslated. The ORF would then encode a protein of 302 amino acids, with a calculated molecular mass of $33900 \mathrm{Da}$. However, the ATG codon is not preceded by a ribosome binding site (RBS), i.e. a sequence complementary to the $3^{\prime}$ end of the 16S rDNA of $A$. calcoaceticus (5'-GATCACCTCCTT3'; C. R. Woese, EMBL data library, acc. no. M34139; Fig. 5). An alternative translation start site in the same reading frame is the TTG codon at position 643 .
Although a UUG codon is thought to be less efficient in initiation of protein synthesis, the TTG codon is preceded by a potential RBS ( $\left.{ }^{632} \mathrm{GGAG}\right)$, with a calculated free energy for binding to the $3^{\prime}$ end of $A$. calcoaceticus $16 \mathrm{~S}$ rRNA of $-39.3 \mathrm{~kJ} \mathrm{~mol}^{-1}$ (Tinoco et al., 1973), and a spacing of 7 nucleotides. This TTG codon may therefore be a good alternative to start translation of the esterase gene (Thach et al., 1966; Kozak, 1983; Hershey, 1987). If translation is initiated from this position, the protein encoded contains 356 amino acids, and has a predicted mass of $40 \cdot 0 \mathrm{kDa}$.

The actual mass of the esterase has not yet been determined. However, the translation start site has been determined via $l a c Z$ fusion strain AAC313-1, in which the est $A$ ORF has been fused in-frame to a promoterless lac $Z$ gene (see Methods and below, Measurements of $\beta$ galactosidase in Acinetobacter lac $Z$ fusion strains). The mass of the fusion product has been measured on Western blots, incubated with polyclonal rabbit antibodies raised against $\beta$-galactosidase. When the ${ }^{805} \mathrm{ATG}$ is used as the start codon, the mass of the EstA- $\beta$ galactosidase fusion product should be increased by roughly $10 \mathrm{kDa}$, relative to the native $\beta$-galactosidase, since the fusion was made at the ${ }^{1071} \mathrm{Sal}$ I site. Translation initiated from the ${ }^{643}$ TTG should result in an increase in mass of about $16 \mathrm{kDa}$. A fusion product was found with a mass increase of about $17 \mathrm{kDa}$ relative to the native $\beta$ galactosidase, identifying the ${ }^{643} \mathrm{TTG}$ as the true translation start codon. The lac $Z$ gene used carries its own RBS. Therefore, apart from the fusion product, native $\beta$ galactosidase can also be formed in AAC313-1. In fact, relatively small amounts of the EstA- $\beta$-galactosidase product were found; the main product formed was the native enzyme, as judged by the relative staining intensity of bands on Western blots. This may be due to the relative inefficiency of TTG as a translation start codon.

Codon usage and codon base composition of the esterase gene are similar to what has been calculated as the average for 20 Acinetobacter genes by White et al. (1991). The esterase gene has a combined $\mathrm{A}+\mathrm{T}$ composition at codon positions one, two and three of $44.9,61.6$ and $66 \cdot 3 \mathrm{~mol} \%$, respectively, exactly matching calculations by White et al. (1991). The overall $\mathrm{A}+\mathrm{T}$ content of the esterase gene $(60 \mathrm{~mol} \%)$, is also in agreement with the A+T content of the Acinetobacter genome (55-62 mol\%; Henriksen, 1976).

Fig. 5. DNA sequence of the $1.83 \mathrm{kbp}$ PvuII/HpaI chromosomal insert in pAKA24-5 encoding an esterase, and predicted amino acid sequence of EstA. The nucleotide sequence was determined via the strategy outlined in Fig. 4. The single large ORF on the nucleotide sequence is underlined. The amino acid sequence derived from this ORF is given, starting from the TTG codon at nucleotide position 643. The potential ribosome-binding site is doubly underlined. Relevant stop codons are marked ***. The two large inverted repeats are overlined. Nucleotides and derived amino acids are numbered to the right. Relevant restriction sites are given above the sequence; 'pAKA10' indicates the Sau 3 A site at nucleotide position 414 , bordering the insert in pAKA10 (see text). 
Table 3. Homology of protein sequences, extracted from data libraries, to A. calcoaceticus BD413 EstA

Data were obtained from the Swiss-Prot and PIR (only human carboxylesterase) data libraries with the sequence comparison program FastA (Pearson and Lipman, 1988). Proteins are only included if they show homology to EstA in an overlap of more than 100 amino acids. When no reference was cited in the data library, only the first author is given, together with the accession number from the data library.

\begin{tabular}{|c|c|c|}
\hline Protein homologous to BD413 EstA (organism) & $\begin{array}{c}\text { Percentage of } \\
\text { amino acids } \\
\text { identical to EstA } \\
\text { (no. of overlapping } \\
\text { amino acids) }\end{array}$ & $\begin{array}{l}\text { Reference and/or } \\
\text { accession no. }\end{array}$ \\
\hline Lipase (Moraxella TA144) & $37 \cdot 2 \%(113)$ & Feller et al. (1991) \\
\hline Hypothetical protein (E. coli) & $38.5 \%(104)$ & Miyamoto et al. (1991) \\
\hline Esterase (A. calcoaceticus RAG-1) & $19 \cdot 1 \%(262)$ & Reddy et al. (1989) \\
\hline Lipase (rat) & $28.7 \%(164)$ & Holm et al. (1988) \\
\hline Vegetative specific protein H5 (Dictyostelium) & $21.4 \%(252)$ & Singleton et al. (P14326) \\
\hline $\begin{array}{l}N \text {-Acetylphosphinothricin-tripetide-deacetylase } \\
\text { (Streptomyces viridochromogenes) }\end{array}$ & $25 \cdot 1 \%(231)$ & Alijah et al. (S20686) \\
\hline Carboxylesterase precursor (mouse) & $26 \cdot 1 \%(134)$ & Ovnik et al. (1991) \\
\hline Liver carboxylesterase precursor (man) & $27 \cdot 6 \%(134)$ & Long et al. (P23141) \\
\hline cDNA encoding a liver carboxylesterase (man) & $26.8 \%(123)$ & Riddles et al. (1991) \\
\hline Proline- $\beta$-naphthylamidase (domestic pig) & $26 \cdot 1 \%(134)$ & Matsushima et al. (1991) \\
\hline Liver carboxylesterase 1 precursor (rat) & $21 \cdot 2 \%(165)$ & Takagi et al. (1988) \\
\hline Juvenile hormone esterase precursor (Heliothis virescens) & $22 \cdot 3 \%(139)$ & Hanzlik et al. (1989) \\
\hline Liver carboxylesterase 1 precursor (rabbit) & $27.0 \%(126)$ & Korza \& Ozols (1988) \\
\hline Liver carboxylesterase 2 precursor (rabbit) & $24 \cdot 1 \%(133)$ & Ozols (1989) \\
\hline
\end{tabular}

The amino acid sequence deduced from the ORF shows homology to several proteins from the PIR and Swiss-Prot data libraries, as determined with the sequence comparison program FASTA (Pearson \& Lipman, 1988). The homologous proteins are mainly esterases and some lipases (Table 3). In Fig. 6, the amino acid sequence of the BD413 protein (BD413 EstA) is aligned to the four proteins with the highest degree of homology, using the multiple sequence analysis program PileUp (see Methods). Although homology of the BD413 EstA sequence to the $A$. calcoaceticus RAG-1 esterase (P18773; Reddy et al., 1989) is found in a relatively large overlapping region (Table 3), it is clear from Fig. 6 that specific regions of EstA are more homologous to the other three proteins. For instance, the ${ }^{127} \mathrm{HGGGF}$ sequence found in BD413, also present in all eukaryotic esterases of Table 3 (not shown), is one of the strikingly homologous regions in the sequences of the upper four proteins of Fig. 6, and is not found in the RAG-1 esterase. Some other amino acids, identical in all but the RAG-1 esterase, are also indicated in Fig. 6.

Several amino acids are conserved in all five proteins aligned in Fig. 6 . The sequence ${ }^{199}$ GDSAG in the BD413 esterase is also found in the lipases of Moraxella and rat. The RAG-1 esterase also contains this box, but it contains a cysteine instead of an alanine. This sequence is identical to the Gly- $\mathrm{X}_{1}-$ Ser- $\mathrm{X}_{2}$-Gly box found in lipases and esterases, as well as in serine proteinases (Brenner, 1988; Boel et al., 1988). The serine in this sequence is probably the nucleophilic residue in the catalytic triad of these enzymes, consisting of an additional histidine and aspartate (Blow, 1990; Brady et al., 1990; Winkler et al., 1990). Although Boel et al. (1988) showed $X_{1}$ to be either tyrosine or histidine in a number of prokaryotic and eukaryotic lipases, the sequences in Fig. 6 all have an aspartate at this position. Also several other residues have been described to occur at the $X_{1}$ and $X_{2}$ positions (Brenner, 1988; Dartois et al., 1992). Interestingly, like the lipolytic enzymes in Fig. 6, almost all serine proteases contain an aspartate at the $X_{1}$ position. However, in these enzymes the $X_{2}$ position is almost invariably a glycine (Brenner, 1988). A histidine (position 85 in EstA) and an aspartate residue (position 104 in EstA) are found in all five proteins, but whether these are the other two residues of the catalytic triad (Blow, 1990), still has to be confirmed for EstA.

No promoter-like sequences (Hoopes \& McClure, 1987) could be identified in the sequence upstream of the esterase ORF. However, two large inverted repeats were found in the sequence of the PvuII/HpaI fragment. The first one is located upstream of $e s t A$, between nucleotides 360 and 396, potentially forming a perfect stem-loop structure, with a stem of 16 nucleotides and a loop of five. This structure has a strongly negative free energy $\left(\Delta G=-120.4 \mathrm{~kJ} \mathrm{~mol}^{-1}\right.$; Tinoco et al., 1973). The program 'Terminator' identified this sequence (or part of it) as a possible rho-independent terminator for transcription (Rosenberg \& Court, 1979), starting from the 


BD413 EgtA
P24484
P23872
P15304
P18773

BD413 Esta P24484 P23872

P15304 P18773

BD413 EstA P24484

P23872

P15304

P18773

BD413 EstA P24484 P23872

P15304

P18773

BD413 EstA P24484

P23872

P15304

P18773

BD413 EstA P24484

P23872

P15304

P18773

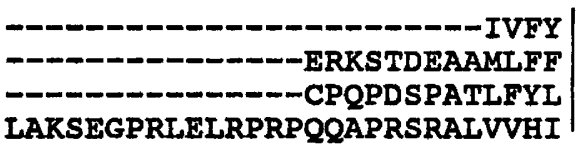

IVFY

IAKSEGPRLELRPRPQQAPRSRALVVHI STNSVWAGGTVGEELSAQSATELILRLF MAVD
*.........

HGGG FVVGNVDTHDEACRL IAKYANAOVIS HGGG FCIGDIDTHHEFCHTVCAQTGWAVVS FILGNLDTHDRIMRLLASYSQCTVIG FVAQTSKSHEPYIRNWAOEIGVPIIS F-LGRLNTHRALMTDPLARASDEVIH
156

194

120

378

90

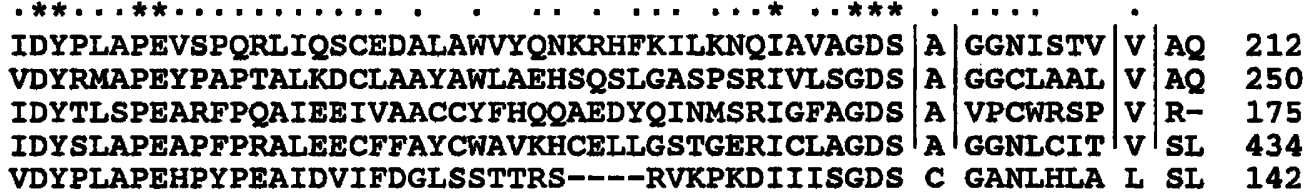

RAI-D-D-GKVYA-OQD-QVI------KPIDALWQDNNQAPAADKKVNDTFKNSLADLPRPLAQLPLYPVTDYEAEY (1) RAAAYGVRVPDGIMAAYPVTTLOSSASPSRLLSLMDPLIPLSVLSKCVSAYSGTETEDHF 494 R-- - - - - - -

- .. . . . .

PSFYAYKDGLVLTGNDVDYV ". PSWELYGEGLLLDHNDAEVF-_-_---NSAYTQHSGLPQSHPLISVMHGDNTQLCPSYI VKLRAFCCGMGFTDYGIPDSDOKALGVMGLVORDTSLFLRDLRLGASSWLNSFLELSGRKPHKTPVACNRDTAPHGFW VSIRSTMHCYRLKALQAGI----------KHYLTDDIQPGDPRVSPLFDDLDGLPPTLV

Fig. 6. Alignment of the predicted amino acid sequence of EstA (BD413 EstA), with the four proteins with the highest homology to EstA. Only part of the amino acid sequences is shown. Data were obtained from the Swiss-Prot protein sequence data library. The numbers at the beginning of each line are the accession numbers of the proteins in the Swiss-Prot library: P24484 is the lipase of Moraxella (Feller et al., 1991), P23872 is the E. coli hypothetical protein (Miyamoto et al., 1991), P15304 is the rat lipase (Holm et al., 1988) and P18773 is the esterase of A. calcoaceticus RAG-1 (Reddy et al., 1989). Homology is indicated above the amino acid sequences; asterisks denote amino acids perfectly conserved in all five proteins and dots denote well-conserved amino acids. Amino acid residues perfectly conserved in all but the RAG-1 esterase are shown between vertical lines. Gaps in the sequences, created by the program, are dashed. Numbers to the right refer to the number of the last amino acid residue on the line, relative to the first amino acid of the protein. Carboxy-terminal amino acids are underlined.

upstream region of est $A$. However, if the inverted repeat sequence between positions 360 and 396 is a terminator for transcription, the distance between it and the end of upstream ORFs is rather long (at least 262 nucleotides).

Interestingly, restriction analysis showed that the insert in pAKA10 starts at position 414 of the sequence in Fig. 5, just downstream of the inverted repeat. Since the level of esterase activity in $E$. coli JM83(pAKA10) is reduced in comparison with strains carrying the larger insert, it is tempting to speculate about the possible role of the 360-396 inverted repeat in regulation of est $A$. This structure, or other sequences on the 414 bp PvuII/Sau3A fragment, may carry promoter functions or form a binding site for a regulatory protein, involved in regulation of estA transcription (Hoopes \& McClure, 1987).

Speculation about the possible role of the $360-396$ inverted repeat in the regulation of est $A$ expression is also fed by the identification of a second large inverted repeat, located 27 nucleotides downstream of the est $A$ ORF (Fig. 5). This sequence, between nucleotides 1731 and 1762, may form a perfect stem-loop, with a stem of 


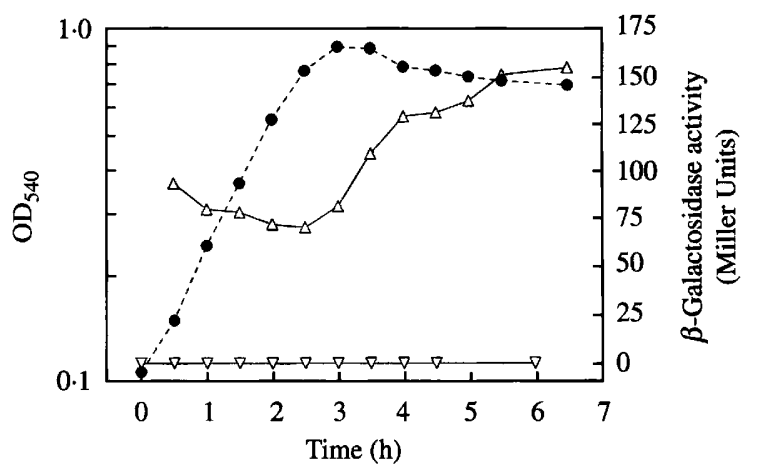

Fig. 7. Production of $\beta$-galactosidase by $\operatorname{lac} Z$ fusion strains of $A$. calcoaceticus. Growth $\left(\mathrm{OD}_{540} ; \boldsymbol{\theta}\right)$ and $\beta$-galactosidase activity (Miller units) were measured in batch cultures of AAC313-1 $(\triangle)$ and AAC313-2 $(\nabla)$, grown in N-broth in well-aerated fermenter vessels. Only the growth curve of AAC313-1 is shown.

14 nucleotides and a loop of four. The structure has a free energy of $-65.2 \mathrm{~kJ} \mathrm{~mol}^{-1}$. Unlike the inverted repeat upstream of the esterase gene, this sequence has no strong similarity to transcription terminators. It lacks the poly-T stretch of nucleotides, normally following the inverted repeat, which serves an important function in rho-independent transcription termination (Rosenberg \& Court, 1979). Also in this case, the structure may be involved in the regulation of gene expression, e.g. of an open reading frame downstream of est $A$.

The possible regulatory role of the two inverted repeats found in the esterase-encoding fragment, together with the function of a potential downstream ORF, are now under investigation.

\section{Measurements of $\beta$-galactosidase in Acinetobacter lac $Z$ fusion strains}

The lacZ-Km cassette of pKOK6, inserted in two orientations between the two SalI sites within the esterase ORF in strains AAC313-1 and AAC313-2, carries a promoterless $l a c Z$ gene. $\beta$-Galactosidase activity was measured in washed cells of these strains grown in $\mathrm{N}$-broth, to confirm the direction of transcription of the esterase gene. Furthermore, the $l a c Z$ fusion strains could aid in unravelling the regulation of the expression of est $A$.

In Fig. 7 , the production of $\beta$-galactosidase is shown during growth of AAC313-1 and AAC313-2 in a batch culture in $\mathrm{N}$-broth. No $\beta$-galactosidase activity could be detected in AAC313-2. However, mutant AAC313-1, carrying the lac $Z$ gene in the same direction as the predicted esterase ORF, did show $\beta$-galactosidase activity. Moreover, like the esterase, the $\beta$-galactosidase was produced at increasing levels during the onset of the stationary phase. Interestingly, in this recombinant strain, a constant level of 75 Miller units $\beta$-galactosidase was produced during exponential growth. A sharp increase in $\beta$-galactosidase level was observed within $1.5 \mathrm{~h}$ after the culture reached the stationary phase of growth. This was followed by a slow increase in the production of $\beta$ galactosidase, up to twice the level produced in the exponential phase.

The $\beta$-galactosidase measurements of Fig. 7, together with the detection of an EstA- $\beta$-galactosidase fusion protein (see above), confirm the direction of transcription predicted by the sequence of the esterase region. Furthermore, the time dependence of $\beta$-galactosidase production in AAC313-1 shows that production of the esterase is regulated at the genetic level. This may be regulation of transcription only, but the possible involvement of growth-phase-dependent mRNA (in)stability and/or regulation at the level of translation cannot be ruled out at this stage.

The molecular mechanism underlying the regulation of est $A$ expression is currently being investigated in lac $Z$ fusion strains, carrying partial deletions of the upstream region of est $A$. The physiological factors involved in transcriptional regulation of the esterase gene will be analysed, as well as the regulation of the production of the extracellular lipase and the second cell-bound esterase.

We are grateful to W. Lotz (University of Erlangen, Germany) for kindly providing pKOK6, to P. Postma for his help in sequence analysis, to $S$. Staal and J. Kwakman for their assistance in sequencing, to M. Jebbink for synthesis of sequencing primers, to I. NugterenRoodzant for expert technical assistance and to $\mathbf{K}$. van Dam and $\mathbf{P}$. Rauch for critically reading the manuscript. This study was financially supported by a grant from the EC.

\section{References}

Bagdasarian, M., Lurz, R., Rückert, B., Franklin, F. C. H., Bagdasarian, M. M., Frey, J. \& Timmis, K. N. (1981). Specificpurpose plasmid cloning vectors. II. Broad host range, high copy number, RSF1010-derived vectors, and a host-vector system for gene cloning in Pseudomonas. Gene 16, 237-247.

BLow, D. (1990). More of the catalytic triad. Nature, London 343 694-695.

Boel, E., Huge-Jensen, B., Christensen, M., Thim, L. \& Fill, N. P. (1988). Rhizomucor miehi triglyceride lipase is synthesized as a precursor. Lipids 23, 701-706.

BRADFORD, M. M. (1976). A rapid and sensitive method for the quantitation of microgram quantities of protein utilizing the principle of protein-dye binding. Analytical Biochemistry 72, 248-254.

Brady, L., Brzozowski, A. M., Derewenda, Z. S., Dodson, E., Dodson, G., Tolley, S., Turkenburg, J. P., Christiansen, L., Huge-Jensen, B., Norskov, L., Thim, L. \& Menge, U. (1990). A serine protease triad forms the catalytic centre of a triacylglycerol lipase. Nature, London 343, 767-770.

BRENNER, S. (1988). The molecular evolution of genes and proteins: a tale of two serines. Nature, London 334, 528-530.

BreuIL, C. \& KuSHNER, D. J. (1975). Lipase and esterase formation by psychrophilic and mesophilic Acinetobacter species. Canadian Journal of Microbiology 21, 423-433.

CASHel, M. \& RuDD, K. E. (1987). The stringent response. In Escherichia coli and Salmonella typhimurium, Cellular and Molecular 
Biology, pp. 1410-1438. Edited by F. C. Neidhardt, J. L. Ingraham, K. Brooks Low, B. Magasanik, M. Schaechter \& H. E. Umbarger. Washington DC: American Society for Microbiology.

Chambers, S. P., Prior, S., Barstow, D. B. \& Minton, N. P. (1988). The pMTL series of cloning vectors: I. Improved polylinker regions to facilitate the generation of sonicated DNA for nucleotide sequencing. Gene 68, 139-149.

CraIG, E. A. \& Gross, C. A. (1991). Is hsp70 the cellular thermometer? Trends in Biochemical Sciences 16, 135-140.

Dartols, V., Baulard, A., Schanck, K. \& Colson, C. (1992). Cloning, nucleotide sequence and expression in Escherichia coli of a lipase from Bacillus subtilis 168. Biochimica et Biophysica Acta 1131, 253-260.

Daza, A., Martín, J. F., Vigal, T. \& Gil, J. A. (1991). Analysis of the promoter region of saf, a Streptomyces griseus gene that increases production of extracellular enzymes. Gene 108, 63-71.

DuBNaU, D. (1991). Genetic competence in Bacillus subtilis. Microbiological Reviews 55, 395-424.

Feller, G., ThiRy, M. \& Gerday, C. (1991). Nucleotide sequence of the lipase gene lip2 from the antarctic psychrotroph Moraxella TA144 and site-specific mutagenesis of the conserved serine and histidine residues. DNA and Cell Biology 10, 381-388.

FisHeR, B. E., KoslowsKi, R., EICHLER, W. \& KLEBER, H.-P. (1987). Biochemical and immunological characterization of lipase during its secretion through cytoplasmic and outer membrane of Acinetobacter calcoaceticus 69 V. Journal of Biotechnology 6, 271-280.

Gibson, T. J. (1984). Studies on the Eppstein-Barr virus genome. $\mathrm{PhD}$ thesis, Cambridge University, UK.

Goldman, E. \& JAKUBOWSKI, H. (1990). Uncharged tRNA, protein synthesis, and the bacterial stringent response. Molecular Microbiology 4, 2035-2040.

Gutnick, D. L., Allon, R., Levy, C., Petter, R. \& Minas, W. (1991). In The Biology of Acinetobacter (FEMS Symposium no. 57), pp. 411-441. Edited by K. J. Towner, E. Bergogne-Bérézin \& C. A. Fewson. New York \& London: Plenum Press.

HAFERBURG, D. \& KLEBER, H.-P. (1983). Regulation der extracellulären Lipase aus einem alkanverwertenden Stamm von Acinetobacter. Acta Biotechnologica 3, 185-186.

HaNaHAN, D. (1983). Studies on transformation of Escherichia coli with plasmids. Journal of Molecular Biology 166, 557-580.

Hanzlik, T. N., Yehia, A. I. A.-A., Harshman, L. G. \& Hammock, B. D. (1989). Isolation and sequencing of cDNA clones coding for juvenile hormone esterase from Heliothis virescens. Journal of Biological Chemistry 264, 12419-12425.

HelmanN, J. D. \& Chamberlin, M. J. (1988). Structure and function of bacterial sigma factors. Annual Review of Biochemistry 57, 839-872.

Henriksen, S. D. (1976). Moraxella, Neisseria, Branhamella and Acinetobacter. Annual Review of Microbiology 30, 63-83.

HERSHEY, J. W. B. (1987). Protein synthesis. In Escherichia coli and Salmonella typhimurium, Cellular and Molecular Biology, pp. 613647. Edited by F. C. Neidhardt, J. L. Ingraham, K. Brooks Low, B. Magasanik, M. Schaechter \& H. E. Umbarger. Washington, DC: American Society for Microbiology.

Holm, C., Kirchgessner, T. G., Svenson, K. L., Lusis, A. J., BelfraGe, P. \& SCHOTZ, M. C. (1988). Nucleotide sequence of rat adipose hormone sensitive lipase cDNA, Nucleic Acids Research 16, 9879.

HoOpes, B. C. \& MCCluRE, W. R. (1987). Strategies in regulation of transcription initiation. In Escherichia coli and Salmonella typhimurium, Cellular and Molecular Biology, pp. 1231-1240. Edited by F. C. Neidhardt, J. L. Ingraham, K. Brooks Low, B. Magasanik, M. Schaechter \& H. E. Umbarger. Washington, DC: American Society for Microbiology.

Hopwood, D. A., Bibb, M. J., Chater, K. F., Janssen, G. R., MalPartida, F. \& SMith, C. P. (1986). Regulation of gene expression in antibiotic-producing Streptomyces. In Regulation of Gene Expression - 25 years on (Symposium 39 of the Society for General Microbiology), pp. 251-276. Edited by I. R. Booth \& C. F. Higgins. Cambridge: Cambridge University Press.

IsH-HORowiCZ, D. \& BuRKE, J. F. (1981). Rapid and efficient cosmid cloning. Nucleic Acids Research 9, 2989-2998.
JUNI, E. (1972). Interspecies transformation of Acinetobacter: genetic evidence for a ubiquitous genus. Journal of Bacteriology 112, 917-931.

JuNI, E. \& JANIK, A. (1969). Transformation of Acinetobacter calcoaceticus (Bacterium anitratum). Journal of Bacteriology 98, 281-288.

KoKOTEK, W. \& LoTz, W. (1989). Construction of a lacZ-kanamycinresistance cassette, useful for site-directed mutagenesis and as a promoter probe. Gene 84, 467-471.

KorZA, G. \& OzoLs, J. (1988). Complete covalent structure of $60-\mathrm{kDa}$ esterase isolated from 2,3,7,8-tetrachlorodibenzo-p-dioxin-induced rabbit liver microsomes. Journal of Biological Chemistry 263, 3486-3495.

KoUKER, G. \& JAEGER, K.-E. (1987). Specific and sensitive plate assay for bacterial lipases. Applied and Environmental Microbiology 53, 211-213.

KozAK, M. (1983). Comparison of initiation of protein synthesis in procaryotes, eucaryotes, and organelles. Microbiological Reviews 47, $1-45$.

LAEMMLI, U. K. (1970). Cleavage of structural proteins during the assembly of the head of bacteriophage T4. Nature, London 227, 680-685.

LANGE, R. \& HENGGe-ARONIS, R. (1991). Identification of a central regulator of stationary-phase gene expression in Escherichia coli. Molecular Microbiology 5, 49-59.

Losick, R., Kroos, L., Errington, J. \& Youngman, P. (1989). Pathways of developmentally regulated gene expression in Bacillus subtilis. In Genetics of Bacterial Diversity, pp. 221-242. Edited by D. A. Hopwood \& K. F. Chater. London: Academic Press.

MANDEL, M. \& HigA, A. (1970). Calcium-dependent bacteriophage DNA infection. Journal of Molecular Biology 53, 159-162.

Martín, J. F. \& LiRAs, P. (1989). Organization and expression of genes involved in the biosynthesis of antibiotics and other secondary metabolites. Annual Review of Microbiology 43, 173-206.

MATIN, A. (1991). The molecular basis of carbon-starvation-induced general resistance in Escherichia coli. Molecular Microbiology $\mathbf{5}$, 3-10.

Matsushima, M., Inoue, H., Ichinose, M., Tsukada, S., Miki, K., Kurokawa, K., Takahashi, T. \& Takahashi, K. (1991). The nucleotide and deduced amino acid sequences of porcine liver proline- $\beta$-naphthylamidase - evidence for the identity with carboxylesterase. FEBS Letters 293, 37-41.

McKay, D. B., Jennings, M. P., Godfrey, E. A., MacRae, I. C., RoGERs, P. J. \& BEACHAM, I. R. (1992). Molecular analysis of an esterase-encoding gene from a lipolytic psychrotrophic pseudomonad. Journal of General Microbiology 138, 701-708.

Miller, J. H. (1982). Experiments in Molecular Genetics. Cold Spring Harbor, NY: Cold Spring Harbor Laboratory.

Miyamoto, K., NaKahigashi, K., Nishimura, K. \& InOKUChI, H. (1991). Isolation and characterization of visible light-sensitive mutants of Escherichia coli K12. Journal of Molecular Biology 219, 393-398.

Mourey, A. \& KILbertus, G. (1976). Simple media containing stabilized tributyrin for demonstrating lipolytic bacteria in foods and soils. Journal of Applied Bacteriology 40, 47-51.

Nilsson, B., UhléN, M., Josephson, S., Gatenbeck, S. \& Philipson, L. (1983). An improved positive selection plasmid vector constructed by oligonucleotide mediated mutagenesis. Nucleic Acids Research 11, 8019-8029.

NitsCh, B. \& KutZneR, H. J. (1969). Egg-yolk agar as a diagnostic medium for Streptomyces. Experientia 25, 220-221.

Ovnic, M., Tepperman, K., Medda, S., Elliott, R. W., Stephenson, D. A., Grant, S. G. \& Ganschow, R. E. (1991). Characterization of a murine cDNA encoding a member of the carboxylesterase multigene family. Genomics 9, 344-354.

OzoLs, J. (1989). Isolation, properties, and the complete amino acid sequence of a second form of $60-\mathrm{kDa}$ glycoprotein esterase. Journal of Biological Chemistry 264, 12533-12545.

Palmen, R., Vosman, B., Buijsman, P., Breek, C. K. D. \& HeLLINGWERF, K. J. (1993). Physiological characterization of natural transformation in Acinetobacter calcoaceticus. Journal of General Microbiology 139, 295-305. 
Pearson, W. R. \& Lipman, D. J. (1988). Improved tools for biological sequence comparison. Proceedings of the National Academy of Sciences of the United States of America 85, 2444-2448.

Reddy, P. G., Allon, R., Mevarech, M., Mendelovitz, S., Sato, Y. \& GUTNICK, D. L. (1989). Cloning and expression in Escherichia coli of an esterase-coding gene from the oil-degrading bacterium Acinetobacter calcoaceticus RAG-1. Gene 76, 145-152.

Riddles, P. W., Richards, L. J., Bowles, M. R. \& Pond, S. M. (1991). Cloning and analysis of a cDNA encoding a human liver carboxylesterase. Gene 108, 289-292.

ROSENBERG, M. \& COURT, D. (1979). Regulatory sequences involved in the promotion and termination of RNA transcription. Annual Review of Genetics 13, 319-353.

Sambrook, J., Fritsch, E. F. \& Maniatis, T. (1989). Molecular Cloning: a Laboratory Manual, 2nd edn. Cold Spring Harbor, New York: Cold Spring Harbor Laboratory.

SANGER, F., Nicklen, S. \& Coulson, A. R. (1977). DNA sequencing with chain-terminating inhibitors. Proceedings of the National Academy of Sciences of the United States of America 74, 5463-5467.

ShabTaI, Y. \& GuTNICK, D. L. (1985). Exocellular esterase and emulsan release from the cell surface of Acinetobacter calcoaceticus RAG-1. Journal of Bacteriology 161, 1176-1181.

Siegele, D. A. \& Kolter, R. (1992). Life after log. Journal of Bacteriology 174, 345-348.

Stragier, P. \& Losick, R. (1990). Cascades of sigmafactors revisited. Molecular Microbiology 4, 1801-1806.

Takagi, Y., Morohashi, K., Kawabata, S., Go, M. \& OmUra, T. (1988). Molecular cloning and nucleotide sequence of cDNA of microsomal carboxyesterase E1 of rat liver. Journal of Biochemistry 104, 801-806.

Thach, R. E., Sundararajan, T. A., Dewey, K., Brown, J. C. \&
Doty, P. (1966). Translation of synthetic messenger RNA. Cold Spring Harbor Symposia on Quantitative Biology 31, 85-97.

Tinoco, I., JR, Borer, P. N., DengleR, B., LeVINE, M. D., UhlenbeCK, O. C., Crothers, D. M. \& Gralla, J. (1973). Improved estimation of secondary structure of ribonucleic acids. Nature, London 246, $40-41$.

Towbin, H., Staehelin, T. \& Gordon, J. (1979). Electrophoretic transfer of proteins from polyacrylamide gels to nitrocellulose sheets: procedure and some applications. Proceedings of the National Academy of Sciences of the United States of America 76, 4350-4354

Vosman, B. \& Hellingwerf, K. J. (1991). Molecular cloning and functional characterization of the recA analog from Pseudomonas stutzeri and construction of a $P$. stutzeri recA mutant. Antonie van Leeuwenhoek 59, 115-123.

Vosman, B., KoK, R. \& Hellingwerf, K. J. (1991). Random insertional mutagenesis in Acinetobacter. In The Biology of Acinetobacter (FEMS Symposium no. 57), pp. 183-189. Edited by K. J. Towner, E. Bergogne-Bérézin \& C. A. Fewson. New York \& London: Plenum Press.

White, P. J., Hunter, I. S. \& Fewson, C. A. (1991). Codon usage in Acinetobacter structural genes. In The Biology of Acinetobacter (FEMS Symposium no. 57), pp. 251-257. Edited by K. J. Towner, E. Bergogne-Bérézin and C. A. Fewson. New York \& London: Plenum Press.

Willis, A. T. \& Gowland, G. (1962). Some observations on the mechanism of the Nagler reaction. Journal of Pathology and Bacteriology 83, 219-226.

WiNKLER, F. K., D'ARCY, A. \& HunZiKer, W. (1990). Structure of human pancreatic lipase. Nature, London 343, 771-774.

YANISCh-Perron, C., VieIRA, J. \& Messing, J. (1985). Improved M13 phage cloning vectors and host strains: nucleotide sequences of the M13mp18 and pUC19 vectors. Gene 33, 103-119. 